Article

\title{
Degradation of Thiol Collectors Using Ozone at a Low Dosage: Kinetics, Mineralization, Ozone Utilization, and Changes of Biodegradability and Water Quality Parameters
}

\author{
Pingfeng $\mathrm{Fu}^{1,2, * \mathbb{D}}$, Xiaofeng Lin ${ }^{1}$, Gen $\mathrm{Li}^{1}{ }^{1}$, Zihao Chen ${ }^{1}$ and Hua Peng ${ }^{1}$ \\ 1 School of Civil and Resources Engineering, University of Science and Technology Beijing, \\ Beijing 100083, China; lxf1120120338@163.com (X.L.); lone0622@163.com (G.L.); \\ 18810969392@163.com (Z.C.); 13051510851@163.com (H.P.) \\ 2 Key Laboratory of High-Efficient Mining and Safety of Metal Mines, Ministry of Education, \\ Beijing 100083, China \\ * Correspondence: pffu@ces.ustb.edu.cn; Tel.: +86-135-2020-2167
}

Received: 16 September 2018; Accepted: 19 October 2018; Published: 24 October 2018

\begin{abstract}
Ozonation at a high $\mathrm{O}_{3}$ dosage can achieve high efficiencies in removing flotation reagents but it has a low ozone-utilization rate. The ozonation of potentially toxic thiol collectors (potassium ethyl xanthate (EX), sodium diethyl dithiocarbamate (SN-9), O-isopropyl- $N$-ethyl thionocarbamate (Z-200) and dianilino dithiophoshoric acid (DDA)) was investigated in an ozone-bubbled reactor at a low $\mathrm{O}_{3}$ dosage of $1.125 \mathrm{mg} /(\mathrm{min} \cdot \mathrm{L})$. The degradation kinetics, mineralization, ozone utilization, changes of biodegradability, and water quality parameters were studied, and the degradation behaviors of four collectors were compared. Thiol collectors could be effectively degraded with a removal ratio of $>90 \%$ and a mineralization ratio of $10-27 \%$, at a low $\mathrm{O}_{3}$ dosage. The ozonation of thiol collectors followed the pseudo first-order kinetics, and rate constants had the order of $k_{\mathrm{SN}-9}>k_{\mathrm{EX}}>k_{\mathrm{Z}-200}>k_{\mathrm{DDA}}$. The Z-200 and DDA were the refractory flotation reagents treated in the ozonation process. After ozonation, the biodegradability of EX, SN-9, and DDA solutions was remarkably raised, but the biodegradability of Z-200 only increased from 0.088 to 0.15 , indicating that the Z-200 and its intermediates were biologically persistent organics. After ozonation, the solution $\mathrm{pH}$ decreased from 10.0 to 8.0-9.0, and both the conductivity and oxidation-reduction potential increased. The ozone utilization ratio in decomposing thiol collectors was above $98.41 \%$, revealing almost complete usage of input $\mathrm{O}_{3}$. The results revealed that thiol collectors could be effectively degraded by $\mathrm{O}_{3}$, even at a low dosage, but their degradation behaviors were quite different, due to intrinsic molecular properties.
\end{abstract}

Keywords: thiol collectors; flotation effluents; ozone; mineralization; biodegradability; ozone utilization; water quality parameters

\section{Introduction}

Froth flotation is extensively used to separate valuable minerals from sulfide ores. Thiol collectors, including xanthates, dithiophosphates, and dithiocarbamates, are important flotation reagents which can render sulfide minerals hydrophobic and facilitate bubble attachments [1]. As a huge amount of sulfide ores are treated annually by froth flotation, the quantities of consumed collectors are extremely large. Even in the 1980s, the global xanthate consumption per year was estimated to be more than 52,000 tons [2]. Therefore, thiol collectors and derived byproducts can be frequently encountered in 
flotation effluents. The hazards of xanthate to humans or aquatic lives have been comprehensively reviewed [3,4].

To reduce water consumption in mineral processing, the flotation effluents should be circulated into flotation circuits. However, in most cases, residual flotation reagents and their byproducts have negative effects on mineral flotation because these compounds can randomly alter the chemistry of flotation system $[5,6]$. Therefore, it is necessary to remove residual reagents from flotation effluents to improve water quality of flotation feeding water.

In the past decades, numerous methods have been developed to remove organic reagents from flotation effluents, such as coagulation and precipitation [7], adsorption [8], chemical oxidation [9], advanced oxidation [10-12], and biodegradation [13,14]. Adsorption is an efficient and simple technique in removing flotation reagents, but further treatment of sludge with toxic reagents and high water content becomes very difficult. The chemical oxidation with oxidants such as sodium hypochlorite often results in secondary pollution [9]. The biodegradation is a low-cost process for treating flotation effluents. However, the long treatment period [14] and the toxicity of some reagents to microbes $[13,15]$ have limited its application in treating flotation effluents.

Recently, advanced oxidation processes (AOPs), involving ozone [10,11], Fenton's reagents [16], hydrogen peroxide [17], persulfate [18], photocatalysis [19], and photoelectrooxidation [20] have been studied to degrade organic flotation reagents, especially xanthates. As hydroxyl radicals $(\cdot \mathrm{OH})$ have an oxidation-reduction potential (ORP) of $2.8 \mathrm{~V}$, the AOPs have exhibited high efficiency in decomposing flotation reagents and their intermediates. However, most of these reports have just been limited to the removal of xanthates $[10,11,19,20]$, and little attention is paid to degrading the other thiol collectors, such as dithiophosphates and dithiocarbamates. Since the molecular structures of thiol collectors are quite different, their decomposition behaviors by the AOPs may be different from each other.

Among above mentioned AOPs, ozonation is one of the most promising processes in decomposing organic pollutants. Ozonation at a high $\mathrm{O}_{3}$ dosage can effectively decompose xanthates with a remarkable reduction of COD and generation of $\mathrm{SO}_{4}{ }^{2-}$ ions $[10,11]$. In the flotation of sulfide ores, the pulp pH is usually kept at 9-12 [21,22]. Thus, the alkalinity of flotation effluents can enhance the ozonation of organic reagents as $\mathrm{OH}^{-}$ions are the catalyst in decomposing $\mathrm{O}_{3}$ to generate. $\mathrm{OH}[23,24]$. Additionally, from the viewpoints of practical applications, ozone can be generated in situ, using air or oxygen as sources, in mines, avoiding the transportation and storage of dangerous chemical oxidants such as $\mathrm{H}_{2} \mathrm{O}_{2}$ [17] and sodium hypochlorite [9]. Therefore, ozonation is considered to be an appropriate technique to treat flotation effluents in mines.

However, ozonation is somewhat disputed for high energy consumption in $\mathrm{O}_{3}$ generation $[25,26]$. Thus the ozone utilization becomes very critical in economic valuation of ozonation. In our previous study, $\mathrm{O}_{3}$ utilization in degrading $n$-butyl xanthate ranged from 7.2 to $51.7 \%$ at the $\mathrm{O}_{3}$ dosage of $5.88-50.36 \mathrm{mg} /(\mathrm{min} \cdot \mathrm{L})$ [11]. Even when ultraviolet radiation (UV) was combined to promote the decomposition of $\mathrm{O}_{3}$, the $\mathrm{O}_{3}$ utilization in $\mathrm{UV} / \mathrm{O}_{3}$ process only increased by $15-30 \%$, compared to pure $\mathrm{O}_{3}$ [11]. Liu et al. [10] observed fast degradation of butyl xanthate at high $\mathrm{O}_{3}$ dosage of $145.59 \mathrm{mg} /(\mathrm{min} \cdot \mathrm{L})$, but the $\mathrm{O}_{3}$ utilization was not concerned. As the reagent concentration in flotation pulps is usually $10^{-3}-10^{-4} \mathrm{~mol} / \mathrm{L}$ [27], the pollutant concentration in flotation effluents is much lower than that of pharmaceutical effluents and petrochemical wastewaters [28,29]. In ozonation, a lower concentration of organics usually leads to a declined $\mathrm{O}_{3}$ decomposition rate, resulting in lower ozone utilization. Thus, a lower $\mathrm{O}_{3}$ dosage might achieve a higher $\mathrm{O}_{3}$ utilization, in the treatment of flotation effluents. Therefore, it is necessary to investigate the degradation efficiencies of flotation reagents and ozone utilization at low $\mathrm{O}_{3}$ dosage.

In this study, four thiol collectors, potassium ethyl xanthate (EX), sodium diethyl dithiocarbamate (SN-9), O-isopropyl-N-ethyl thionocarbamate (Z-200), and dianilino dithiophoshoric acid (DDA), were selected as the sulfide mineral collectors. The $\mathrm{O}_{3}$ dosage was controlled to be as low as $1.125 \mathrm{mg} /(\mathrm{min} \cdot \mathrm{L})$, much lower than that previously used in the ozonation of xanthates $[10,11]$. The aims of this work were, (1) to investigate degradation kinetics, mineralization, and changes 
of biodegradability and water quality parameters in degrading thiol collectors using $\mathrm{O}_{3}$, (2) to compare degradation efficiencies of thiol collectors with different molecular structures, and (3) to evaluate the ozone utilization and energy consumption efficiency at a low $\mathrm{O}_{3}$ dosage. The result can provide fundamental aspects of ozone utilization and degradation behaviors of potentially toxic sulfide mineral collectors, at a low $\mathrm{O}_{3}$ dosage.

\section{Materials and Methods}

\subsection{Chemicals}

The EX and SN-9 with analytical grade were purchased from Shanghai Aladdin Chemical Reagent Co., Ltd., Shanghai, China. The Z-200 and industrial grade DDA were purchased from Tieling Flotation Reagents Co. Ltd., China. Their molecular formulas, molecular structures, and abbreviations used are summarized in Table 1. By storing the collectors in a brown vacuum desiccator, they were separated from air and radiation, to prevent the oxidation. Other chemicals, such as iodine $\left(\mathrm{I}_{2}\right)$, potassium iodide (KI), silver sulfate $\left(\mathrm{Ag}_{2} \mathrm{SO}_{4}\right)$, mercury sulfate $\left(\mathrm{HgSO}_{4}\right)$, and potassium bichromate $\left(\mathrm{K}_{2} \mathrm{Cr}_{2} \mathrm{O}_{7}\right)$ were of analytical grade and were purchased from Sinopharm Chemical Reagent Beijing Co., Ltd., Beijing, China. In all experiments, deionized water was used.

Table 1. Collector name, molecular formula, molecular structure, and abbreviations used in this work.

\begin{tabular}{|c|c|c|c|}
\hline Collector Name & Molecular Formula & Molecular Structure & Abbreviation \\
\hline $\begin{array}{l}\text { potassium ethyl } \\
\text { xanthate }\end{array}$ & $\mathrm{C}_{2} \mathrm{H}_{4} \mathrm{OCS}_{2} \mathrm{~K}$ & $\mathrm{CH}_{3}-\mathrm{CH}_{2}-\mathrm{O}-\stackrel{\stackrel{\mathrm{S}}{\|}}{\mathrm{C}}-\mathrm{S}-\mathrm{K}$ & EX \\
\hline $\begin{array}{l}\text { sodium diethyl } \\
\text { dithiocarbamate }\end{array}$ & $\left(\mathrm{C}_{2} \mathrm{H}_{5}\right)_{2} \mathrm{NCSSNa}$ & $\begin{array}{l}\mathrm{CH}_{3}-\mathrm{CH}_{2} \\
\mathrm{CH}_{3}-\mathrm{CH}_{2}^{\prime}\end{array}$ & SN-9 \\
\hline $\begin{array}{l}\text { O-isopropyl-N-ethyl } \\
\text { thionocarbamate }\end{array}$ & $\left(\mathrm{CH}_{3}\right)_{2} \mathrm{CHOCSNHC}_{2} \mathrm{H}_{5}$ & 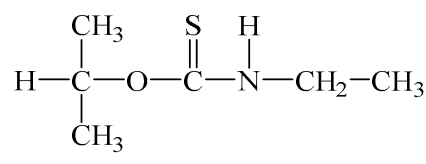 & Z-200 \\
\hline $\begin{array}{c}\text { dianilino } \\
\text { dithiophoshoric acid }\end{array}$ & $\left(\mathrm{C}_{6} \mathrm{H}_{5} \mathrm{NH}\right)_{2} \mathrm{PSSH}$ & & DDA \\
\hline
\end{tabular}

\subsection{Experimental Procedures}

All the degradation experiments were conducted with a batch mode in a jacket glass bubbled reactor connected to a thermostatic bath. The schematic diagram of experimental setup is shown in Figure 1. The cylindrical reactor, with a height of $1150 \mathrm{~mm}$ and internal diameter of $50 \mathrm{~mm}$, was installed with a porous glass plate at the bottom to distribute the $\mathrm{O}_{3}$ stream. Ozone was generated with air as the source, by an $\mathrm{O}_{3}$ generator (SW-004, Qingdao West Electronic Purifiers Co., Qingdao, China). The $\mathrm{O}_{3}$ stream was introduced into the reactor with a steady-state $\mathrm{O}_{3}$ concentration of $1347 \mathrm{mg} / \mathrm{m}^{3}$ and at a gas flow rate of $0.1 \mathrm{~m}^{3} / \mathrm{h}$. The degradation experiments were carried out at $25 \pm 2{ }^{\circ} \mathrm{C}$.

Prior to degradation experiments, the collector $(0.2 \mathrm{~g})$ was dissolved in $2 \mathrm{~L}$ deionized water to prepare an EX (SN-9, Z-200 or DDA) solution of $100 \mathrm{mg} / \mathrm{L}$ concentration. The initial $\mathrm{pH}$ was adjusted to 10.0 with $0.05 \mathrm{~mol} / \mathrm{L} \mathrm{NaOH}$ or $\mathrm{HCl}$ solution. While $2 \mathrm{~L}$ collector solution was introduced into the reactor, bubbled with an $\mathrm{O}_{3}$ stream, the degradation began at the $\mathrm{O}_{3}$ dosage of $1.125 \mathrm{mg} /(\mathrm{min} \cdot \mathrm{L})$. As, the four different collectors had different degradation efficiencies, to achieve the collector removal 
ratio of $90-100 \%$, for the comparison, the ozonation time was chosen to be $90,90,120$, and 180 min for the EX, SN-9, Z-200, and DDA, respectively. The aqueous samples were taken at designed intervals to determine the concentrations of collector, $\mathrm{SO}_{4}{ }^{2-}$ ions, $\mathrm{COD}, \mathrm{BOD}_{5}$, and $\mathrm{TOC}$. The water quality parameters ( $\mathrm{pH}$, conductivity, oxidation-reduction potential (ORP)) were measured by immersing the electrodes into solutions as shown in Figure 1.

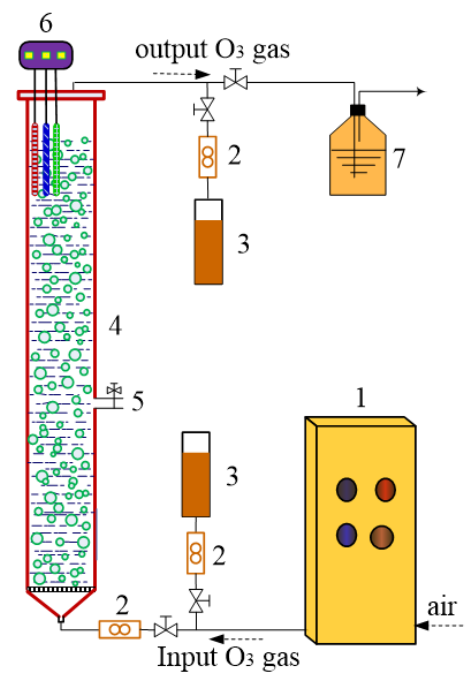

Figure 1. Schematic diagram of experimental setup. 1-ozone generator; 2-flow meter; 3-KI absorption liquid for measuring $\mathrm{O}_{3}$ concentration; 4-bubbled cylindrical reactor; 5—sampling valve; 6-multi-parameter water quality meter (pH electrode, ORP electrode, conductivity probe); 7-ozone destructor bottle with KI solution.

\subsection{Analysis and Calculation}

\subsubsection{Determination of the Collector Concentration}

The xanthate concentration has always been determined by the UV-vis spectroscopic method. However, this method has seldom been reported to measure the concentration of the SN-9, Z-200 and DDA [13]. Figure 2a showed the UV-vis absorbance spectra of EX, SN-9, Z-200, and DDA solutions recorded by a UV-vis spectrophotometer (UV-5500PC, Shanghai Metash Instruments Co. Ltd., Shanghai, China). The maximum absorption peaks appeared at $301 \mathrm{~nm}$ for EX, $256 \mathrm{~nm}$ for SN-9, $241 \mathrm{~nm}$ for Z-200, and $230 \mathrm{~nm}$ for DDA solution, respectively. The plots of the collector concentration versus absorbance at its characteristic absorption wavelength are shown in Figure $2 b$. The correlation coefficients $(>0.99)$ indicated that calibration curves could be used to calculate the collector concentration by recording its absorbance.
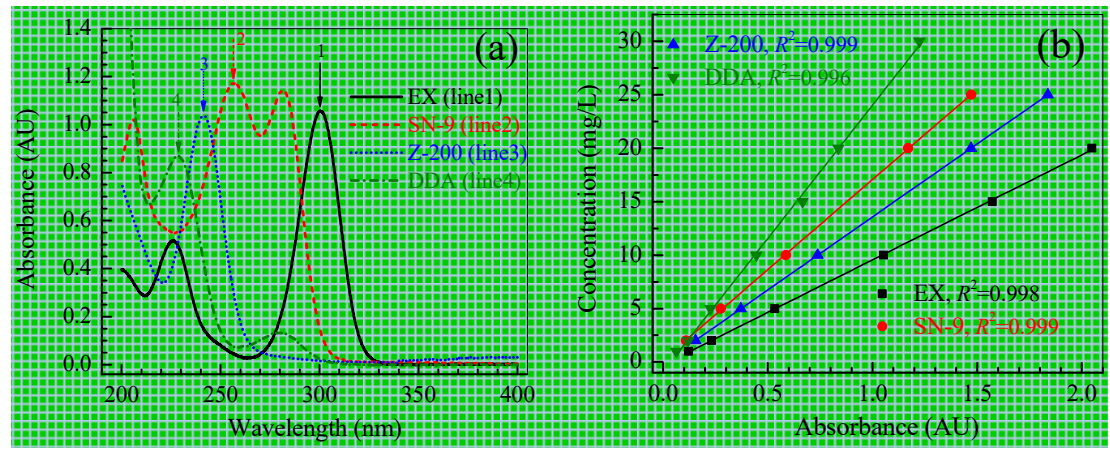

Figure 2. UV-vis absorbance spectra for the four collector solutions, at $20 \mathrm{mg} / \mathrm{L}$ concentration (a); and the collector concentration versus the absorbance of collector solutions (b). 
Thus, in this work, the concentration of four collectors was determined by the UV-vis spectroscopic method. The removal ratio of the collector was calculated as the following:

$$
\beta_{\text {collector }}=\frac{C_{0}-C_{t}}{C_{0}} \times 100 \%
$$

where $\beta_{\text {collector }}$ was the removal ratio of the collector (EX, SN-9, Z-200 or DDA), $C_{0}$ and $C_{t}(\mathrm{mg} / \mathrm{L})$ were the collector concentration at initial and time $t$, respectively.

\subsubsection{Determination of $\mathrm{COD}, \mathrm{BOD}_{5}, \mathrm{TOC}$, and Concentration of $\mathrm{SO}_{4}{ }^{2-}$ ions}

The chemical oxygen demand (COD) was determined by the standard dichromate method (HJ/T 399-2007). The biochemical oxygen demand $\left(\mathrm{BOD}_{5}\right)$ was detected by the classic dilution and inoculation method (HJ 505-2009). The aqueous samples were incubated at $20^{\circ} \mathrm{C}$, for 5 days. The total organic carbon (TOC) concentrations were measured using a Shimadzu TOC-V organic carbon analyzer. The concentration of $\mathrm{SO}_{4}{ }^{2-}$ ions was determined by a barium chromate spectrophotometry method (HJ/T 342-2007). In this study, the removal ratio of COD was obtained by Equation (2), as follows:

$$
\beta_{\mathrm{COD}}=\frac{C O D_{0}-C O D_{\mathrm{t}}}{C O D_{0}} \times 100 \%
$$

where $\beta_{\mathrm{COD}}$ was the removal ratio of $\mathrm{COD}, C O D_{0}$ and $C O D_{\mathrm{t}}(\mathrm{mg} / \mathrm{L})$ were the $\mathrm{COD}$ concentration at initial and time $t$, respectively.

The carbon mineralization ratio was calculated by Equation (3), as follows:

$$
\gamma_{C}=\frac{T O C_{0}-T O C_{t}}{T O C_{0}} \times 100 \%
$$

where $\gamma_{C}$ was the carbon mineralization ratio of the collector, and $T O C_{0}$ and $T O C_{t}(\mathrm{mg} / \mathrm{L})$ were the TOC concentration at initial and time $t$, respectively. As the $\mathrm{SO}_{4}{ }^{2-}$ ions, with the highest valence of sulfur, were the final products during the oxidation of organic sulfur in thiol collectors, the sulfur mineralization ratio was defined by Equation (4), as follows:

$$
\gamma_{\mathrm{S}}=\frac{M}{n \times 96} \times \frac{C_{\mathrm{SO}_{4}^{2-}, \mathrm{t}}}{C_{0}} \times 100 \%
$$

where $\gamma_{S}$ was the sulfur mineralization ratio of the collector, $M$ and $n$ were the molecular weight and number of sulfur atom in the collector molecule (EX, SN-9, Z-200 or DDA), respectively, $\mathrm{C}_{\mathrm{SO}_{4}^{2-}, \mathrm{t}}$ was the concentration of $\mathrm{SO}_{4}{ }^{2-}$ ions at time $t$, and $\mathrm{C}_{0}(\mathrm{mg} / \mathrm{L})$ was initial collector concentration.

\subsubsection{Analysis of Water Quality Parameters}

Water quality parameters of ozonated solutions, including solution $\mathrm{pH}$, conductivity and ORP, were measured by a multi-parameter water quality meter equipped with different electrodes (Bante 900-UK, Shanghai Bante Instruments Co. Ltd., Shanghai, China). The solution pH was measured by a $\mathrm{pH}$ combination electrode (P11 mode). Before the measurement, it was calibrated with buffer solutions of $\mathrm{pH} 4.01,7.00$ and 10.01. The conductivity was determined by a glass conductivity probe with platinum cells (K10 mode). The ORP was recorded using an epoxy ORP electrode (501 mode), which was composed of a platinum pin and $\mathrm{Ag} / \mathrm{AgCl}$ reference electrode.

\subsubsection{Analysis of Gaseous $\mathrm{O}_{3}$ Concentration}

The gaseous $\mathrm{O}_{3}$ concentration was determined by the KI absorption method (CJ/T 3028.2-94). The $\mathrm{O}_{3}$ concentration in the output $\mathrm{O}_{3}$ gas was measured after $30 \mathrm{~min}$ of ozonation to meet the 
solubility equilibrium of $\mathrm{O}_{3}$ in solutions. The ozone utilization ratio was calculated by Equation (5), as follows:

$$
\eta_{\mathrm{O} 3}=\frac{C_{\mathrm{O} 3, \text { in }}-C_{\mathrm{O} 3, \text { out }}}{C_{\mathrm{O} 3 \text {,in }}} \times 100 \%
$$

where $\eta_{\mathrm{O} 3}$ was the ozone utilization ratio, $C_{\mathrm{O} 3 \text {,in }}$ and $C_{\mathrm{O} 3 \text {,out }}\left(\mathrm{mg} / \mathrm{m}^{3}\right)$ were the $\mathrm{O}_{3}$ concentration in input and output $\mathrm{O}_{3}$ gas streams, respectively.

\section{Results and Discussion}

\subsection{Degradation Kinetics of Thiol Collectors}

The degradation behaviors of thiol collectors by $\mathrm{O}_{3}$ are shown in Figure 3a. Figure 3b illustrated the logarithmic plot of $\ln \left(C_{t} / C_{0}\right)$ versus ozonation time $t$, and kinetic parameters were summarized in Table 2. As shown in Figure 3a, EX, and SN-9 were rapidly degraded by $\mathrm{O}_{3}$, but the degradation of Z-200 and DDA were much slower. At $90 \mathrm{~min}$, the removal ratio of EX and SN-9 was close to 100\%, but only $87.38 \%$ of the Z-200 and $79.71 \%$ of the DDA were removed. By extending the ozonation time, $98.39 \%$ of Z-200 could be removed at $120 \mathrm{~min}$, but only $90.91 \%$ of DDA was degraded even at $180 \mathrm{~min}$. As shown in Figure $3 \mathrm{~b}$ and Table 2, the removal of thiol collectors by $\mathrm{O}_{3}$ could be well described by the pseudo first-order kinetic models. By comparing rate constant of $k_{\text {collector }}$ it could be seen that the degradation by $\mathrm{O}_{3}$, for the four collectors, followed the order of $k_{\mathrm{SN}-9}>k_{\mathrm{EX}}>k_{\mathrm{Z}-200}>k_{\mathrm{DDA}}$. Especially, the $k_{\text {collector }}$ of SN-9 and EX was almost three times higher than that of Z-200 and DDA. The results revealed that in terms of ozonation, the SN-9 and EX could be easily decomposed, but the Z-200 and DDA were refractory flotation reagents.
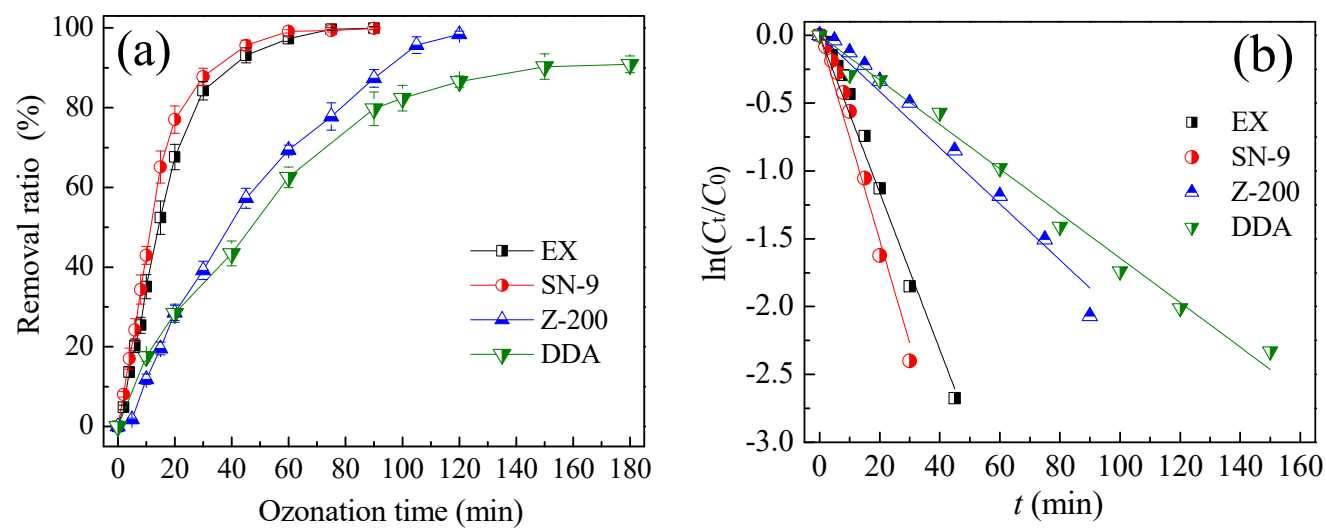

Figure 3. The variations of the removal ratio of thiol collectors with ozonation time (a) and the pseudo-first-order kinetic fitting of $\ln \left(C_{t} / C_{0}\right)$ versus ozonation time $t(\mathbf{b})$.

Table 2. Kinetic equations, pseudo-first-order rate constants $\left(k_{\text {collector }}\right)$, half-life time $\left(t_{1 / 2}\right)$ and correlation coefficients $\left(R^{2}\right)$ in the ozonation of thiol collectors.

\begin{tabular}{ccccc}
\hline Collector & Kinetic Equation & $\boldsymbol{k}_{\text {collector }}\left(\mathbf{m i n}^{-\mathbf{1}}\right)$ & $\boldsymbol{t}_{\mathbf{1 / 2}}(\mathbf{m i n})$ & $\boldsymbol{R}^{\mathbf{2}}$ \\
\hline EX & $C_{\mathrm{t}}=C_{0} \cdot \mathrm{e}^{-0.0579 t}$ & 0.0579 & 11.97 & 0.9903 \\
SN-9 & $C_{\mathrm{t}}=C_{0} \cdot \mathrm{e}^{-0.0687 t}$ & 0.0687 & 10.09 & 0.9918 \\
Z-200 & $C_{\mathrm{t}}=C_{0} \cdot \mathrm{e}^{-0.0194 t}$ & 0.0194 & 35.69 & 0.9835 \\
DDA & $C_{\mathrm{t}}=C_{0} \cdot \mathrm{e}^{-0.0164 t}$ & 0.0164 & 42.27 & 0.9967 \\
\hline
\end{tabular}

Due to low operation cost, the biodegradation has been tested to degrade some flotation reagents. The first-order biodegradation rate constants of SN-9 and Z-200 were reported to be $3.13 \times 10^{-4}$ and $4.17 \times 10^{-5} \mathrm{~min}^{-1}$, respectively [13]. By comparing the $k_{\mathrm{SN}-9}\left(0.0687 \mathrm{~min}^{-1}\right)$ and $k_{\mathrm{Z}-200}\left(0.0194 \mathrm{~min}^{-1}\right)$ in Table 2, it was clear that the rate constant in ozonation was two-three orders higher than that in the 
biodegradation of same flotation reagent. The ozonation even at a low $\mathrm{O}_{3}$ dosage achieved a much higher efficiency than the biodegradation in degrading flotation reagents.

Nowadays, residual flotation reagents are usually removed in tailing ponds with a natural degradation process. The first-order rate constant of EX natural degradation has been reported by Sun et al. [4] to be $2.094 \times 10^{-5} \mathrm{~min}^{-1}$, with a half-life of 22.99 day, at $\mathrm{pH} 7$ and $25^{\circ} \mathrm{C}$, and have been given by Shen et al. [30] to be $1.55 \times 10^{-5} \mathrm{~min}^{-1}$, at $\mathrm{pH} 6.8$ and $20^{\circ} \mathrm{C}$. Chen et al. [31] observed almost no natural degradation of $\mathrm{EX}$ at a $\mathrm{pH} \geq 5$, in $4 \mathrm{~h}$. However, for the EX degradation, the ozonation at a low $\mathrm{O}_{3}$ dosage of $1.125 \mathrm{mg} /(\mathrm{min} \cdot \mathrm{L})$ could achieve the $k_{\mathrm{EX}}$ of $0.0579 \mathrm{~min}^{-1}$, with a half-life of $11.97 \mathrm{~min}$. Therefore, compared to a natural degradation process, ozonation at low $\mathrm{O}_{3}$ dosage can effectively degrade flotation reagents, within a much shorter treatment time.

\subsection{Carbon and Sulfur Mineralization of Thiol Collectors}

In the ozonation of the thiol collectors, the concentrations of $\mathrm{COD}, \mathrm{TOC}$, and $\mathrm{SO}_{4}{ }^{2-}$ ions were measured, as illustrated in Figure 4. For all collectors investigated, the concentration of both COD and TOC decreased with the increase of $\mathrm{SO}_{4}{ }^{2-}$ concentration while the collector was degraded. Compared to the significant decrease of COD, the decline of TOC was much slower. As shown in Table 3, at the collector removal ratio of $>90 \%$, the removal ratio of COD was approximately below $62 \%$ and the carbon mineralization ratio $\left(\gamma_{C}\right)$ was just lower than $27 \%$, respectively. When comparing the rate constants of collector and COD removal (summarized in Tables 2 and 3), the $k_{\text {collector value was }}$ found to be 2-10 times higher than the $k_{\mathrm{COD}}$, for each collector. It was revealed that only a small fraction of carbon in thiol collectors was completely mineralized by $\mathrm{O}_{3}$, although all of the above $90 \%$ of collectors were decomposed. In the ozonation of $n$-butyl xanthate, $n$-butanol was detected by UPLC/Q-TOF-MS [32], and O-butyl peroxydithiocarbonate was found [11]. Thus, it could be reasonably inferred that most organic carbon in thiol collectors were still in the forms of reductive organic intermediates, after the ozonation.
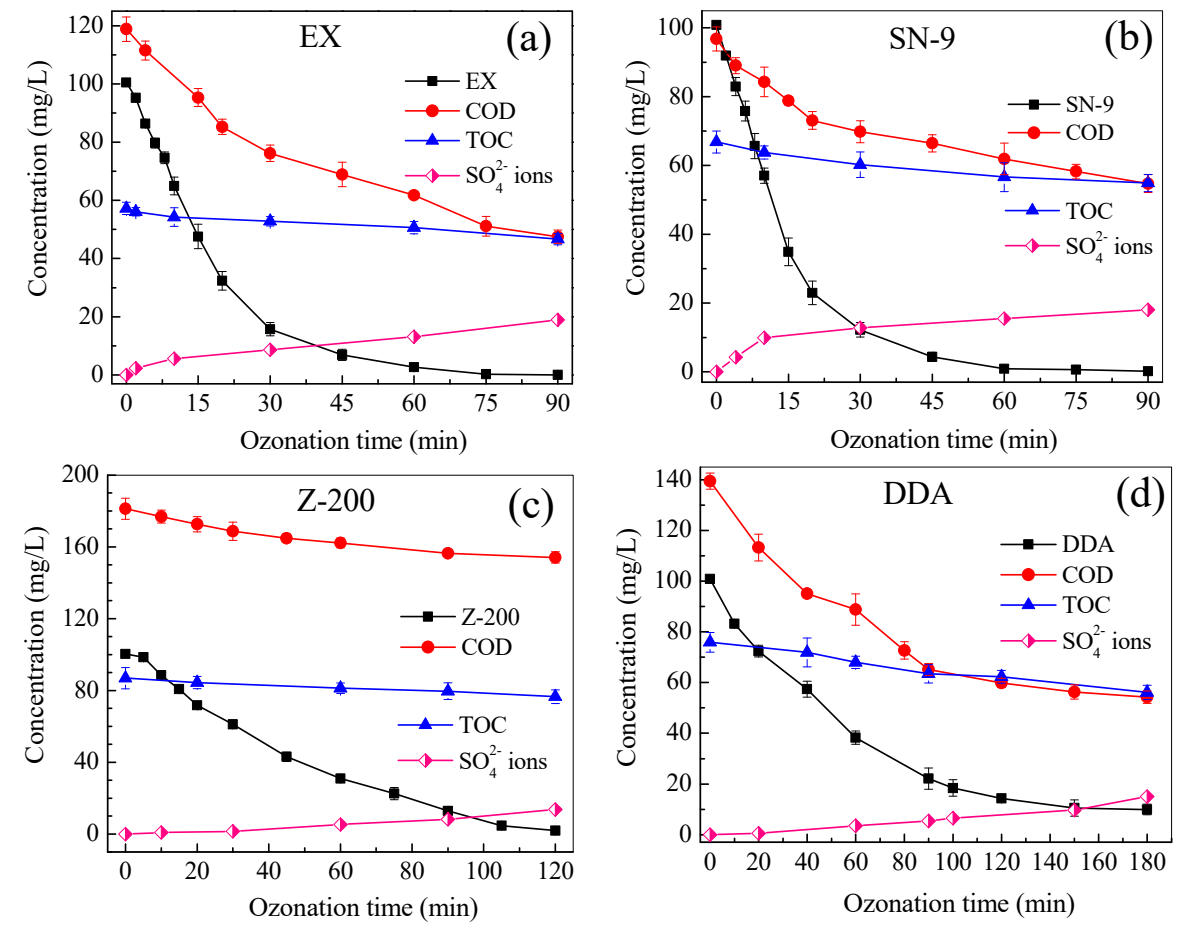

Figure 4. The variations of the concentration of collector, $\mathrm{COD}, \mathrm{TOC}$, and $\mathrm{SO}_{4}{ }^{2-}$ ions with ozonation time in the degradation of EX (a), SN-9 (b), Z-200 (c), and DDA (d).

As illustrated in Figure 4, the concentration of $\mathrm{SO}_{4}{ }^{2-}$ ions increased to $18.93 \mathrm{mg} / \mathrm{L}$ for EX, $18.07 \mathrm{mg} / \mathrm{L}$ for SN-9, $13.65 \mathrm{mg} / \mathrm{L}$ for Z-200, and $15.01 \mathrm{mg} / \mathrm{L}$ for DDA, respectively, at the end of 
ozonation. The generation of the $\mathrm{SO}_{4}{ }^{2-}$ ions indicated the complete oxidation of organic sulfur in the thiol collectors. However, as given in Table 3, the sulfur mineralization ratio $\left(\gamma_{\mathrm{S}}\right)$ was just below $22 \%$, indicating that some sulfur byproducts, such as $\mathrm{CS}_{2}, \mathrm{~S}^{2-}$ and organics containing sulfur, might exist in solutions [10,11,30,32]. As volatile sulfur species such as $\mathrm{CS}_{2}$ and $\mathrm{H}_{2} \mathrm{~S}$ were generated, they may have been emitted from ozone-bubbled solutions into a gas phase, resulting in lower $\gamma_{S}$ values. For example, Yan et al. [32] had inferred the emitting of 20.6\% sulfur into the gas phase in decomposing $n$-butyl xanthate by $\mathrm{O}_{3}$. Generally, in this work, the mineralization ratio of carbon and sulfur for the four collectors ranged from $10 \%$ to $27 \%$, at the collector removal ratio of above $90 \%$.

Table 3. The removal ratio of the collector and the COD, the carbon and sulfur mineralization ratio, and the pseudo-first-order rate constants for COD removal, in the ozonation of thiol collectors.

\begin{tabular}{ccccccc}
\hline \multirow{2}{*}{ Collector } & $\begin{array}{c}\text { Removal Ratio of } \\
\text { Collector (\%) }\end{array}$ & $\begin{array}{c}\text { Removal Ratio of } \\
\text { COD (\%) }\end{array}$ & $\begin{array}{c}\boldsymbol{k}_{\text {COD }} \\
\left(\mathbf{m i n}^{-1}\right)\end{array}$ & $\boldsymbol{R}^{\mathbf{2}}$ & Carbon & Sulfur \\
\cline { 3 - 7 } EX & $99.98(90 \mathrm{~min})$ & $60.04(90 \mathrm{~min})$ & 0.0111 & 0.9843 & $18.42(90 \mathrm{~min})$ & $11.95(90 \mathrm{~min})$ \\
\hline SN-9 & $99.87(90 \mathrm{~min})$ & $43.47(90 \mathrm{~min})$ & 0.00694 & 0.9838 & $17.84(90 \mathrm{~min})$ & $21.21(90 \mathrm{~min})$ \\
\hline \multirow{2}{*}{ Z-200 } & $87.38(90 \mathrm{~min})$ & $13.67(90 \mathrm{~min})$ & 0.00188 & 0.9858 & $8.31(90 \mathrm{~min})$ & $12.54(90 \mathrm{~min})$ \\
& $98.37(120 \mathrm{~min})$ & $14.97(120 \mathrm{~min})$ & & & & Mineralization Ratio (\%) \\
\multirow{2}{*}{ DDA } & $79.71(90 \mathrm{~min})$ & $53.25(90 \mathrm{~min})$ & 0.00779 & 0.9888 & $16.35(90 \mathrm{~min})$ & $20.92(120 \mathrm{~min})$ \\
\hline & $90.91(180 \mathrm{~min})$ & $61.11(180 \mathrm{~min})$ & & & $26.05(180 \mathrm{~min})$ & $21.98(180 \mathrm{~min})$ \\
\hline
\end{tabular}

As given in Table 3, the $\gamma_{C}$ of Z-200 at 90 min was just $8.31 \%$, much lower than that of EX, SN-9, and DDA at $90 \mathrm{~min}$. The $k_{\mathrm{COD}}$ of EX, SN-9, and DDA was 5.91, 3.69, and was 4.14 folds higher than that of Z-200, respectively. It clearly revealed that the intermediates derived from the Z-200 were hardly oxidized by $\mathrm{O}_{3}$. Although the DDA was very refractory in the ozonation, the $\gamma_{C}$ of the DDA was close to that of EX and SN-9 at 90 min, indicating that its intermediates could be readily decomposed by $\mathrm{O}_{3}$. By considering $\gamma_{\mathrm{C}}$ and $\gamma_{\mathrm{S}}$ together, the mineralization of four collectors by $\mathrm{O}_{3}$ had the following order: $\mathrm{SN}-9 \approx \mathrm{EX}>\mathrm{DDA}>\mathrm{Z}-200$.

In general, ozonation reactions are divided into two main pathways-direct ozone oxidation, occurring at $\mathrm{pH}<4.0$ and indirect ozone oxidation, occurring at $\mathrm{pH}>10.0$. At the $\mathrm{pH}$ of 4.0-10.0, both pathways exist, but direct ozone oxidation becomes predominant in the neutral and weak acid medium [33,34]. As shown in Figure 5, the solution pH decreased from 10.0, initially, to 8.0-9.0 at the end of ozonation. Therefore, in this case, the direct ozone oxidation might have greatly contributed to the collector decomposition during most of the ozonation period. Unfortunately, the direct oxidation of organics by $\mathrm{O}_{3}$ has some disadvantages of low reaction rate and strong selectivity, as compared to oxidation by free radicals [35-37]. Thus, the intermediates, hardly oxidized by $\mathrm{O}_{3}$ molecules, should be accumulated in the solutions.
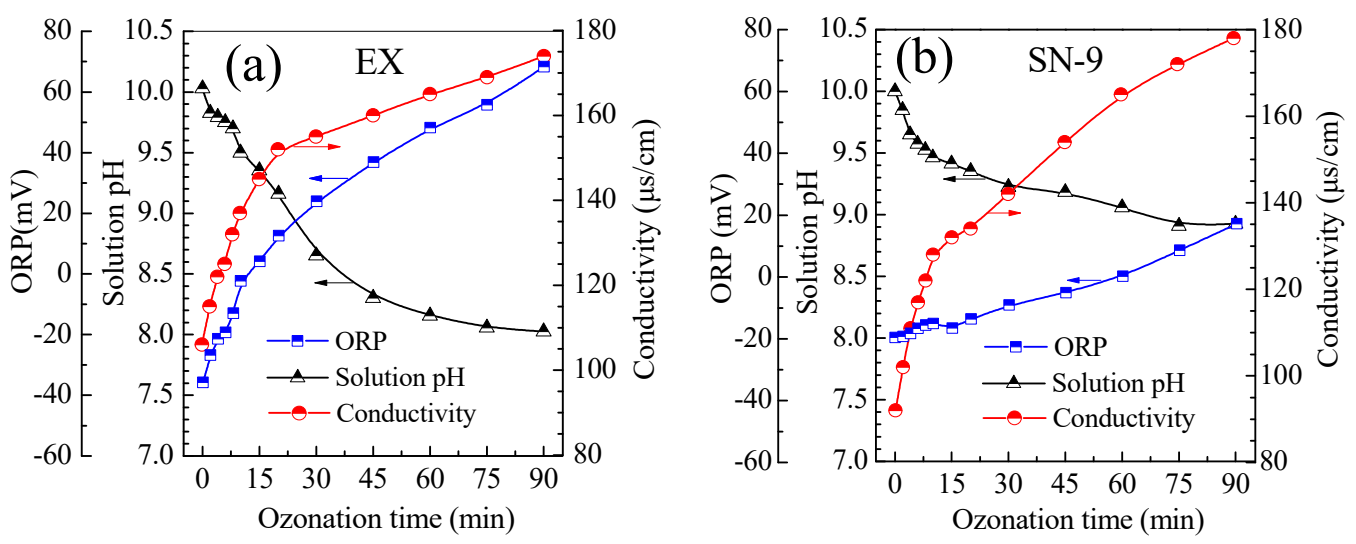

Figure 5. Cont. 

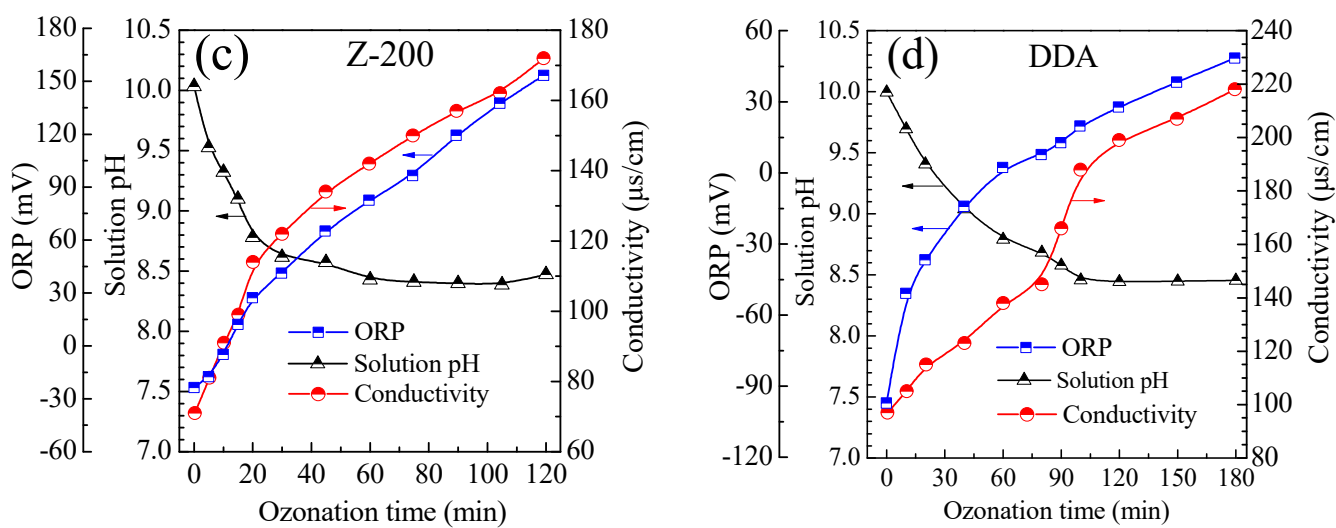

Figure 5. The variations of solution $\mathrm{pH}$, conductivity, and ORP, with ozonation times, in the degradation of EX (a), SN-9 (b), Z-200 (c), and DDA (d).

\subsection{Variation of Biodegradability}

Although biodegradation is a low-cost procedure for removing organic pollutants, some flotation reagents, such as $n$-butyl xanthate [10], butyl amine aerofloat [10], ethylthionocarbamate [13], turpentine [38], isopropyl xanthate [39], and aniline aerofloat [40], are hardly biodegraded due to their special molecular structures. However, the intermediates derived by $\mathrm{O}_{3}$, from these reagents, might become biodegradable [10]. Thus, a combined ozonation and biodegradation process may be more feasible than ozonation or biodegradation alone, in treating flotation effluents.

In this study, the variation of biodegradability of thiol collectors, before and after ozonation, was investigated. As shown in Figure 6, the $\mathrm{BOD}_{5} / \mathrm{COD}$ for EX, SN-9, Z-200, and DDA solutions before the ozonation was $0.33,0.19,0.088$, and 0.12 , respectively. In general, organic pollutants with the $\mathrm{BOD}_{5} / \mathrm{COD}$ of $>0.3$ are considered to be biodegradable [10]. Thus, it was clear that excepting the EX, the SN-9, Z-200, and DDA were biologically persistent flotation reagents. After ozonation for $90 \mathrm{~min}$, the $\mathrm{BOD}_{5} / \mathrm{COD}$ for $\mathrm{EX}, \mathrm{SN}-9$, and DDA solutions increased to $0.73,0.31$, and 0.32 , respectively, indicating the generation of biodegradable intermediates. However, the $\mathrm{BOD}_{5} / \mathrm{COD}$ for Z-200 solution just increased from 0.088 to 0.15 , after ozonation for $120 \mathrm{~min}$, revealing that its intermediates were still hardly biodegraded. It can be seen that both the Z-200 and its intermediates were biologically persistent organics. For all four collectors investigated, the increase of the biodegradability, after the ozonation, followed the order of EX $>$ DDA $\approx$ SN-9 $>$ Z-200.

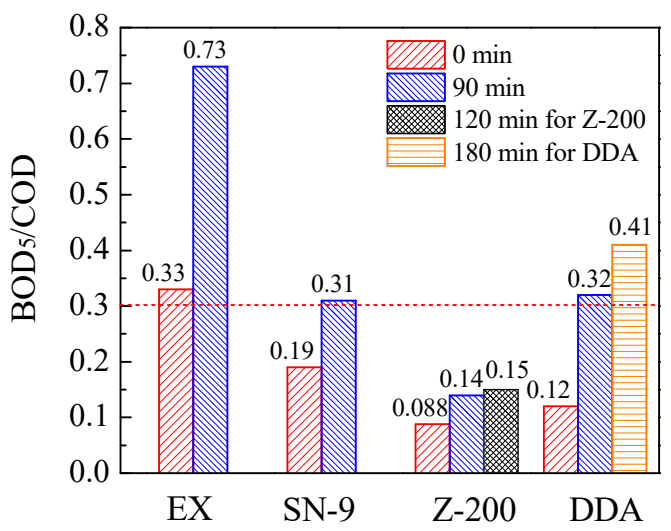

Figure 6. The biodegradability of collector solutions before and after the ozonation, for different treatment times.

\subsection{Evolution of Solution $p H, O R P$ and Conductivity}

In the flotation of sulfide minerals, solution parameters such as pulp $\mathrm{pH}$ and ORP are very important in determining the floatability of minerals and interaction of flotation reagents with 
minerals [41-44]. Since treated flotation effluents will be reused in flotation circuits as feeding water, the changes of both solution parameters and reagent concentrations should be revealed to better understand the quality of reused flotation water. However, in the previous works of degrading flotation reagents by $\mathrm{O}_{3}[10,11,32], \mathrm{H}_{2} \mathrm{O}_{2}$ [31], Fenton reagents [45], and sodium hypochlorite [9], little attention was paid to revealing the evolution of solution parameters, except for the $\mathrm{pH}$ value.

In this work, the solution $\mathrm{pH}, \mathrm{ORP}$, and conductivity in degrading collectors were recorded as shown in Figure 5. For four collectors studied, the solution $\mathrm{pH}$ was declined from 10.0 to 8.0-9.0, and the increase of the conductivity reached $68,86,101$, and $121 \mu \mathrm{s} / \mathrm{cm}$ for EX, SN-9, Z-200, and DDA solution, respectively, at the collector removal ratio of $>90 \%$. The indirect ozonation reactions were initiated with catalytic decomposition of $\mathrm{O}_{3}$ by $\mathrm{OH}^{-}$ions, as shown in Equations (6)-(11) [23,24]. The chain reactions of $\mathrm{O}_{3}$ decomposition could generate free radicals, such as $\mathrm{OH}, \mathrm{HO}_{2}$, and $\cdot \mathrm{O}_{2}{ }^{-}$, which were responsible for breaking the chemical bonds of organics. Thus $\mathrm{H}^{+}$ions were continually dissociated from $\mathrm{H}_{2} \mathrm{O}$, with an observed decrease of solution $\mathrm{pH}$. In addition, simple carboxylic acids, such as formic and acetic acids could be generated via indirect reactions [46,47], which also contributed to the acidity of collector solutions. Thus, the $\mathrm{pH}$ of collector solutions was decreased after the ozonation.

$$
\begin{gathered}
\mathrm{H}_{2} \mathrm{O} \leftrightarrow \mathrm{H}^{+}+\mathrm{OH}^{-} \\
\mathrm{O}_{3}+\mathrm{OH}^{-} \rightarrow \mathrm{HO}_{2}+\mathrm{O}_{2}^{-} \\
\mathrm{HO}_{2} \rightarrow \mathrm{H}^{+}+\mathrm{O}_{2}^{-} \\
\mathrm{O}_{3}+\mathrm{O}_{2}^{-} \rightarrow \mathrm{O}_{3}^{-}+\mathrm{O}_{2} \\
\mathrm{O}_{3}^{-}+\mathrm{H}^{+} \rightarrow \mathrm{HO}_{3} \\
\mathrm{HO}_{3} \rightarrow \mathrm{OH}+\mathrm{O}_{2}
\end{gathered}
$$

In the degradation of xanthates by $\mathrm{O}_{3}$ or $\mathrm{H}_{2} \mathrm{O}_{2}$, inorganic ions, such as $\mathrm{S}^{2-}, \mathrm{S}_{2} \mathrm{O}_{3}{ }^{2-}, \mathrm{SO}_{4}{ }^{2-}$ and $\mathrm{CO}_{3}{ }^{2-}$ were observed to be readily generated [10,11,31]. Ionized intermediates, such as $O$-ethyl thiocarbonate $\left(\mathrm{ETC}^{-}\right)$and $O$-ethyl peroxydithiocarbonate $\left(\mathrm{EPX}^{-}\right)$were also detected in the oxidation of EX by $\mathrm{H}_{2} \mathrm{O}_{2}$ [17]. Therefore, the increase of conductivity directly revealed that some ionic intermediates were generated in the ozonation of collectors. The higher conductivity in Figure 5 corresponded to a lower concentration of collector and COD, as shown in Figure 4.

In the ozonation process, it is frequently observed that the ozone consumption rate will remarkably decrease with a rapid increase of the ORP and the reduction of pollutant removal efficiency, while the pollutant concentration goes below a certain value $[48,49]$. So, the ORP is a useful indicator in the control of $\mathrm{O}_{3}$ addition, to minimize the process cost $[48,50,51]$. For the mineral flotation, the ORP is found to determine the oxidation of collectors and speciation of metal ions $[41,44]$. Thus, the revelation of ORP evolution is very important for both the control of $\mathrm{O}_{3}$ addition and the reuse of treated flotation effluents.

As shown in Figure 5, the ORP of collector solutions, before ozonation, was negative. As the ozonation reactions occurred, the ORP increased up to $68.3,17.2,150.3$, and $48.4 \mathrm{mV}$ for EX, SN-9, Z-200, and DDA solutions, at the end of ozonation, respectively. The variations of COD concentration with the ORP are shown in Figure 7. The ORP of ozonated solutions increased with the reduction of the COD for the four collectors. Thus, it can be inferred that a certain correlation should exist between the COD and ORP of ozonated solutions, which might allow the ORP, as the indicator, to control the ozonation process. 


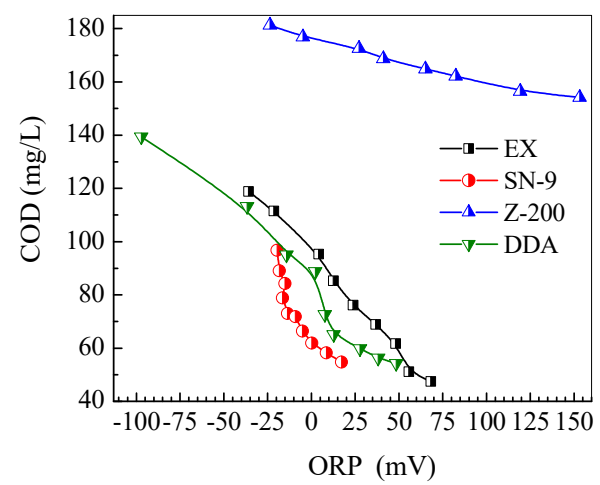

Figure 7. The variations of COD concentration with the ORP of ozonated collector solutions.

\subsection{Ozone Utilization}

At the $\mathrm{O}_{3}$ dosage of $1.125 \mathrm{mg} /(\mathrm{min} \cdot \mathrm{L})$, the $\mathrm{O}_{3}$ input rate was $2.26 \mathrm{mg} / \mathrm{min}$. As shown in Figure 8 , the $\mathrm{O}_{3}$ emitting rate for deionized water at $\mathrm{pH} 10.0$ was just $0.495 \mathrm{mg} / \mathrm{min}$, and the $\mathrm{O}_{3}$ utilization ratio $\left(\eta_{\mathrm{O} 3}\right)$ of $78.01 \%$ was achieved. The color of $\mathrm{KI}$ absorption liquid was changed from a dark red, due to the absorption of the input $\mathrm{O}_{3}$ gas, to a light yellow for the absorption of the $\mathrm{O}_{3}$ emitted from water. The result revealed that $78.01 \%$ of input $\mathrm{O}_{3}$ was dissolved and decomposed in alkaline water. Since $\mathrm{OH}^{-}$ions could catalytically decompose dissolved $\mathrm{O}_{3}$ as given in Equations (6)-(11), the alkalinity of water promoted the dissolution of gaseous $\mathrm{O}_{3}$ into water, resulting in a lower $\mathrm{O}_{3}$ emitting rate. It suggests that the alkalinity of flotation effluents is beneficial to the $\mathrm{O}_{3}$ utilization and generation of free radicals $\left(\mathrm{OH}, \cdot \mathrm{HO}_{2}\right.$ and $\mathrm{O}_{2}{ }^{-}$, etc.). In this work, low $\mathrm{O}_{3}$ dosage should have also contributed to a high $\eta_{\mathrm{O} 3}$, for deionized water.

When the collector concentration was raised from 1 to $100 \mathrm{mg} / \mathrm{L}$, the $\eta_{\mathrm{O} 3}$ shown in Figure $8 \mathrm{~b}$ increased from $94.22 \%$ to $99.89 \%$, for thee EX and from $88.62 \%$ to $99.97 \%$, for the DDA solution, respectively. The color of the $\mathrm{KI}$ absorption liquids, for absorbing the $\mathrm{O}_{3}$ emitted, from the $100 \mathrm{mg} / \mathrm{L}$ EX and DDA solutions was almost white, directly demonstrating nearly no escape of $\mathrm{O}_{3}$ from the reactors. It was very clear that the addition of collectors increased the $\mathrm{O}_{3}$ utilization, which could be attributed to the reactions of $\mathrm{O}_{3}$ molecules, with collectors. As shown in Figure $8 \mathrm{~b}$, the EX had higher $\eta_{\mathrm{O} 3}$ than the DDA, while the concentration was $<10 \mathrm{mg} / \mathrm{L}$. The difference in $\eta_{\mathrm{O} 3}$ directly revealed that the EX was more sensitive in reacting with $\mathrm{O}_{3}$ than the DDA. In this work, at a low $\mathrm{O}_{3}$ dosage of $1.125 \mathrm{mg} /(\mathrm{min} \cdot \mathrm{L})$, the $\eta_{\mathrm{O} 3}$ was close to $100 \%$, in the ozonation of EX and DDA with $100 \mathrm{mg} / \mathrm{L}$ concentration. However, in the ozonation of $n$-butyl xanthate, the achieved $\eta_{\mathrm{O} 3}$ just ranged from $7.2 \%$ to $51.7 \%$, at the $\mathrm{O}_{3}$ dosage of $5.88-50.36 \mathrm{mg} /(\mathrm{min} \cdot \mathrm{L})$ [11]. The results revealed that the ozonation of thiol collectors at a low $\mathrm{O}_{3}$ dosage could achieve almost $100 \%$ utilization of $\mathrm{O}_{3}$, meaning it reduced the treating cost by adding a lesser amount of $\mathrm{O}_{3}$.
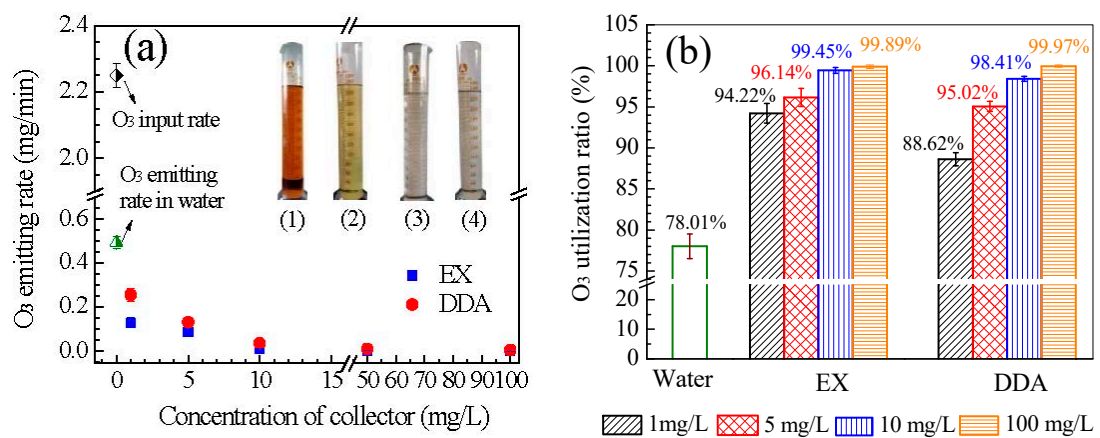

Figure 8. Ozone-emitting rate (a) and $\mathrm{O}_{3}$ utilization ratio (b) in the ozonation of EX and DDA, with different concentrations. The inset figures are photographs of $\mathrm{KI}$ absorption liquids, for absorbing input $\mathrm{O}_{3}$ gas (1), emitted $\mathrm{O}_{3}$ from deionized water (2), EX (3), and DDA (4) solutions with $100 \mathrm{mg} / \mathrm{L}$ concentration, respectively. 


\subsection{Analysis of Energy Consumption Efficiency}

In the treatment of contaminants with AOPs, the electrical energy per order $(E E / O)$ was introduced to directly evaluate the electric efficiency and feasibility of the scale-up of AOPs [52]. This parameter was defined as "the electric energy in $\mathrm{kWh}$ required in degrading a contaminant by one order of magnitude in $1 \mathrm{~m}^{3}$ contaminated water". To calculate the energy requirements for the ozonation, an average energy consumption of $15 \mathrm{kWh} / \mathrm{kg}$ for the $\mathrm{O}_{3}$ production was assumed [53], and the energy calculations were based on a $90 \%$ removal of collectors. $E E / O$ values $\left(\mathrm{kWh} /\left(\mathrm{m}^{3}\right.\right.$. order $\left.)\right)$ were calculated for batch operations as given by Equation (12).

$$
E E / O=\frac{P \times 1000}{V \times 60} \times \frac{\ln 10}{k_{\text {collector }}}
$$

where $P$ was the electric power $(\mathrm{kWh})$ required for producing dosed $\mathrm{O}_{3}, V$ was the volume (L) of test collector solution, and $k_{\text {collector }}$ was the pseudo-first-order constant $\left(\mathrm{min}^{-1}\right)$.

The results of the energy calculation for the ozonation of the four collectors are summarized in Table 4. As shown in Table 2, the $k_{\text {collector }}$ of EX and SN-9 was lower than that of Z-200 and DDA, revealing the higher efficiency in the degradation of EX and SN-9. Thus, the EE/O values for EX and SN-9 removal were much lower than that for Z-200 and DDA. However, at a low $\mathrm{O}_{3}$ dosage of $1.125 \mathrm{mg} /(\mathrm{min} \cdot \mathrm{L})$, the ozonation of all of four collectors was feasible, in terms of energy consumption, since values of $E E / O$, not higher than $10 \mathrm{kWh} /\left(\mathrm{m}^{3}\right.$.order), were considered suitable for practical application [54].

Table 4. Electrical energy per order $(E E / O)$ in the ozonation of the four thiol collectors.

\begin{tabular}{ccccc}
\hline Collector & EX & SN-9 & Z-200 & DDA \\
\hline$E E / O\left(\mathrm{kWh} /\left(\mathrm{m}^{3} \cdot\right.\right.$ order $\left.)\right)$ & 0.45 & 0.33 & 3.18 & 6.06 \\
\hline
\end{tabular}

\section{Conclusions}

Thiol collectors (EX, SN-9, Z-200 and DDA) could be effectively degraded by $\mathrm{O}_{3}$ at a low dosage of $1.125 \mathrm{mg} /(\mathrm{min} \cdot \mathrm{L})$. Both the removal of collectors and the decline of COD followed the pseudo-first-order kinetic models. The ozonation of the four collectors followed the order of $k_{\text {collector: }}$ : $k_{\mathrm{SN}-9}\left(0.0687 \mathrm{~min}^{-1}\right)>k_{\mathrm{EX}}\left(0.0579 \mathrm{~min}^{-1}\right)>k_{\mathrm{Z}-200}\left(0.0194 \mathrm{~min}^{-1}\right)>k_{\mathrm{DDA}}\left(0.0164 \mathrm{~min}^{-1}\right)$. The $k_{\text {collector }}$ in the removing-collectors was 2-10 times higher than the $k_{\mathrm{COD}}$ of COD removal. At the collector removal ratio of $>90 \%$, the mineralization ratio of the four collectors ranged from $10 \%$ to $27 \%$, with the order of SN-9 $\approx \mathrm{EX}>\mathrm{DDA}>\mathrm{Z}-200$. For the four collectors investigated, EX and SN-9 could be easily degraded by $\mathrm{O}_{3}$, but the ozonation of Z-200 and DDA exhibited much lower efficiencies. Especially, both the Z-200 and its intermediates were hardly decomposed by $\mathrm{O}_{3}$.

The SN-9, Z-200, and DDA were found to be biologically persistent flotation reagents as their $\mathrm{BOD}_{5} / \mathrm{COD}$ values were below 0.2. After ozonation, the $\mathrm{BOD}_{5} / \mathrm{COD}$ of $\mathrm{EX}, \mathrm{SN}-9$, and DDA solutions increased to $0.73,0.31$, and 0.41 , respectively, with remarkable increase of the biodegradability. However, the $\mathrm{BOD}_{5} / \mathrm{COD}$ of $\mathrm{Z}-200$ solution increased just from 0.088 to 0.15 , after the ozonation, revealing that its intermediates were still hardly biodegraded. After ozonation, the solution $\mathrm{pH}$ of four collectors decreased from 10.0 to 8.0-9.0, and an increase of conductivity $(68-121 \mu \mathrm{s} / \mathrm{cm}$ ) was observed, exhibiting the generation of various ionic intermediates. For the four collectors, the ORP rapidly increased with the decline of COD concentration, indicating that the ORP might act as the indicator to monitor the ozonation of collectors.

At low $\mathrm{O}_{3}$ dosage of $1.125 \mathrm{mg} /(\mathrm{min} \cdot \mathrm{L})$, the $\eta_{\mathrm{O} 3}$ reached $78.01 \%$ for ionized water at $\mathrm{pH} 10.0$ due to effective $\mathrm{O}_{3}$ decomposition initiated by $\mathrm{OH}^{-}$ions. The addition of collectors significantly enhanced the $\mathrm{O}_{3}$ decomposition. At the collector (EX and DDA) concentration of $>10 \mathrm{mg} / \mathrm{L}$, the $\eta_{\mathrm{O}}$ increased to above $98.41 \%$, revealing an almost complete usage of input $\mathrm{O}_{3}$ at a low $\mathrm{O}_{3}$ dosage. EE/O values revealed that the ozonation of all of four collectors was feasible, in terms of energy consumption. 
Author Contributions: P.F. and H.P. designed the study. G.L. and Z.C. set up the experimental degradation systems. X.L., G.L. and H.P. performed the degradation experiments of four collector solutions and analyzed the water quality parameters ( $\mathrm{pH}, \mathrm{ORP}$ and conductivity) and the concentration of collector, $\mathrm{COD}$ and $\mathrm{SO}_{4}{ }^{2-}$ ions. X.L. and Z.C. carried out the analysis of TOC and ozone concentration in gas phase. All of the authors interpreted experimental results and supported the preparation of the paper. P.F. had revised the manuscript.

Funding: This research was funded by the National Natural Science Foundation of China, grant number 51674017.

Acknowledgments: We were grateful to Center for Environmental Quality Test, Tsinghua University for providing the analysis of $\mathrm{BOD}_{5}$ concentration of collector solution samples.

Conflicts of Interest: The authors declare no conflict of interest.

\section{References}

1. Bulatovic, S.M. Handbook of Flotation Reagents: Chemistry, Theory and Practice, 1st ed.; Elsevier: Amsterdam, The Netherlands, 2010.

2. Somasundaran, P.; Moudgil, B.M. Reagents in Mineral Technology; Marcel Dekker Inc.: New York, NY, USA, 1988.

3. Li, X.F. Teratogenic toxicity of butyl xanthate to frog embryos. Environ. Sci. Acta 1990, 10, $213-216$.

4. Sun, Z.X.; Forsling, W. The degradation kinetics of ethyl xanthate as a function of $\mathrm{pH}$ in aqueous solution. Miner. Eng. 1997, 10, 389-400. [CrossRef]

5. Kemppinen, J.; Aaltonen, A.; Sihvonen, T.; Leppinen, J.; Sirén, H. Xanthate degradation occurring in flotation process waters of a gold concentrator plant. Miner. Eng. 2015, 80, 1-7. [CrossRef]

6. Rao, S.R.; Finch, J.A. A review of water reuse in flotation. Miner. Eng. 1989, 2, 65-85. [CrossRef]

7. Mielczarski, J. The role of impurities of sphalerite in the adsorption of ethyl xanthate and its flotation. Int. J. Miner. Process. 1986, 16, 179-194. [CrossRef]

8. Rezaei, R.; Massinaei, M.; Zeraatkar Moghaddam, A. Removal of the residual xanthate from flotation plant tailings using modified bentonite. Miner. Eng. 2018, 119, 1-10. [CrossRef]

9. Lin, W.X.; Tian, J.; Ren, J.; Xu, P.T.; Dai, Y.K.; Sun, S.Y.; Wu, C. Oxidation of aniline aerofloat in flotation wastewater by sodium hypochlorite solution. Environ. Sci. Pollut. Res. 2016, 23, 785-792. [CrossRef] [PubMed]

10. Liu, R.Q.; Sun, W.; Ouyang, K.; Zhang, L.M.; Hu, Y.H. Decomposition of sodium butyl xanthate (SBX) in aqueous solution by means of OCF: Ozonator combined with flotator. Miner. Eng. 2015, 70, 222-227. [CrossRef]

11. Fu, P.F.; Feng, J.; Yang, T.W.; Yang, H.F. Comparison of alky xanthates degradation in aqueous solution by the $\mathrm{O}_{3}$ and $\mathrm{UV} / \mathrm{O}_{3}$ process: Efficiency, mineralization and ozone utilization. Miner. Eng. 2015, 81, 128-134. [CrossRef]

12. Fu, P.F.; Feng, J.; Yang, H.F.; Yang, T.W. Degradation of $n$-butyl xanthate by vacuum UV-ozone $\left(V U V / \mathrm{O}_{3}\right)$ in comparison with ozone and VUV photolysis. Process Saf. Environ. Prot. 2016, 102, 64-70. [CrossRef]

13. Chen, S.H.; Gong, W.Q.; Mei, G.J.; Zhou, Q.; Bai, C.P.; Xu, N. Primary biodegradation of sulfide mineral flotation collectors. Miner. Eng. 2011, 24, 953-955. [CrossRef]

14. Araujo, D.M.; Yoshida, M.I.; Takahashi, J.A.; Carvalho, C.F.; Stapelfeldt, F. Biodegradation studies on fatty amines used for reverse flotation of iron ore. Int. Biodeterior. Biodegrad. 2010, 64, 151-155. [CrossRef]

15. Jafari, M.; Shafaei, S.Z.A.; Abdollahi, H.; Gharabaghi, M.; Chelgani, S.C. A comparative study on the effect of flotation reagents on growth and iron oxidation activities of Leptospirillum ferrooxidans and Acidithiobacillus ferrooxidans. Minerals 2017, 7, 2. [CrossRef]

16. Mahiroglu, A.; Tarlan-Yel, E.; Sevimli, M.F. Treatment of combined acid mine drainage (AMD)-flotation circuit effluents from copper mine via Fenton's process. J. Hazard. Mater. 2009, 166, 782-787. [CrossRef] [PubMed]

17. Silvester, E.; Truccolo, D.; Hao, F.P. Kinetics and mechanism of the oxidation of ethyl xanthate and ethyl thiocarbonate by hydrogen peroxide. J. Chem. Soc. Perkin Trans. 2002, 2, 1562-1571. [CrossRef]

18. Chen, S.H.; Xiong, P.; Zhan, W.; Xiong, L. Degradation of ethylthionocarbamate by pyrite-activated persulfate. Miner. Eng. 2018, 12, 38-43. [CrossRef]

19. Xiao, Q.; Ouyang, L.L. Photocatalytic photodegradation of xanthate over $\mathrm{Zn}_{1-\mathrm{x}} \mathrm{Mn} x \mathrm{O}$ under visible light irradiation. J. Alloys Compd. 2009, 479, L4-L7. [CrossRef]

20. Molina, G.C.; Cayo, C.H.; Rodrigues, M.A.S.; Bernardes, A.M. Sodium isopropyl xanthate degradation by advanced oxidation processes. Miner. Eng. 2013, 45, 88-93. [CrossRef] 
21. Feng, Q.C.; Wen, S.M.; Zhao, W.J.; Liu, J.; Liu, D. Effect of pH on surface characteristics and flotation of sulfidized cerussite. Physicochem. Probl. Miner. Process. 2016, 52, 676-689. [CrossRef]

22. Gibson, C.E.; Kelebek, S. Sensitivity of pentlandite flotation in complex sulfide ores towards $\mathrm{pH}$ control by lime versus soda ash: Effect on ore type. Int. J. Miner. Process. 2014, 127, 44-51. [CrossRef]

23. Staehelin, J.; Hoigné, J. Decomposition of ozone in water: Rate of initiation by hydroxide ions and hydrogen peroxide. Environ. Sci. Technol. 1982, 16, 676-681. [CrossRef]

24. Yershov, B.G.; Morozov, P.A.; Gordeev, A.V.; Seliverstov, A.F. Kinetic regularities of ozone decomposition in water. J. Water Chem. Technol. 2009, 31, 381-388. [CrossRef]

25. Wu, C.H.; Ng, H.Y. Degradation of C.I. Reactive Red 2 (RR2) using ozone-based systems: Comparisons of decolorization efficiency and power consumption. J. Hazard. Mater. 2008, 152, 120-127. [CrossRef] [PubMed]

26. Katsoyiannis, I.A.; Canonica, S.; von Gunten, U. Efficiency and energy requirements for the transformation of organic micropollutants by ozone, $\mathrm{O}_{3} / \mathrm{H}_{2} \mathrm{O}_{2}$ and $\mathrm{UV} / \mathrm{H}_{2} \mathrm{O}_{2}$. Water Res. 2011, 45, 3811-3822. [CrossRef] [PubMed]

27. Rahman, R.M.; Ata, S.; Jameson, G.J. Study of froth behaviour in a controlled plant environment-Part 2: Effect of collector and frother concentration. Miner. Eng. 2015, 81, 161-166. [CrossRef]

28. Wen, S.H.; Chen, L.; Li, W.Q.; Ren, H.Q.; Li, K.; Wu, B.; Hu, H.D.; Xu, K. Insight into the characteristics, removal, and toxicity of effluent organic matter from a pharmaceutical wastewater treatment plant during catalytic ozonation. Sci. Rep. 2018, 8, 9581. [CrossRef] [PubMed]

29. Ding, P.Y.; Chu, L.B.; Wang, J.L. Advanced treatment of petrochemical wastewater by combined ozonation and biological aerated filter. Environ. Sci. Pollut. Res. 2018, 25, 9673-9682. [CrossRef] [PubMed]

30. Shen, Y.; Nagaraj, D.R.; Farinato, R.; Somasundaran, P. Study of xanthate decomposition in aqueous solutions. Miner. Eng. 2016, 93, 10-15. [CrossRef]

31. Chen, X.H.; Hu, Y.H.; Peng, H.; Cao, X.F. Degradation of ethyl xanthate in flotation residues by hydrogen peroxide. J. Cent. South Univ. 2015, 22, 495-501. [CrossRef]

32. Yan, P.F.; Chen, G.Q.; Ye, M.Y.; Sun, S.Y.; Ma, H.T.; Lin, W.X. Oxidation of potassium n-butyl xanthate with ozone: Products and pathways. J. Clean. Prod. 2016, 139, 287-294. [CrossRef]

33. Beltran-Heredia, J.; Torregrosa, J.; Dominguez, J.R.; Peres, J.A. Kinetics of the reaction between ozone and phenolic acids present in agro-industrial wastewaters. Water Res. 2001, 35, 1077-1082. [CrossRef]

34. Beltran, F.J.; Garcia-Araya, J.F.; Alvarez, P.M. pH sequential ozonation of domestic and wine-distillery wastewaters. Water Res. 2001, 35, 929-936. [CrossRef]

35. Tobiasn, N.; Hans, F.; Clemens, V.S. Ozonation of wastewater: Rate of ozone consumption and hydroxyl radical yield. Environ. Sci. Technol. 2009, 15, 5990-5995. [CrossRef]

36. Hoigné, J.; Bader, H. Rate constants of reactions of ozone with organic and inorganic compounds in water-I Non-dissociating organic compounds. Water Res. 1983, 17, 173-183. [CrossRef]

37. Hoigné, J.; Bader, H. Rate constants of reactions of ozone with organic and inorganic compounds in water-II Dissociating organic compounds. Water Res. 1983, 17, 185-194. [CrossRef]

38. Cheng, H.; Lin, H.; Huo, H.X.; Dong, Y.B.; Xue, Q.Y.; Cao, L.X. Continuous removal of ore floatation reagents by an anaerobic-aerobic biological filter. Bioresour. Technol. 2012, 114, 255-261. [CrossRef] [PubMed]

39. Natarajan, K.A.; Sabari Prakasan, M.R. Biodegradation of sodium isopropyl xanthate by Paenibacillus polymyxa and Pseudomonas putida. Miner. Metall. Process. 2013, 30, 226-232. [CrossRef]

40. Song, W.F.; Chen, X.Q.; Yan, M.; Tang, T.Z.; Li, S.Y. Processing of aniline aerofloat wastewater with SBR system and its biodegradation mechanism. Agric. Sci. Technol. 2013, 14, 1032-1036.

41. López Valdivieso, A.; Sánchez López, A.A.; Ojeda Escamilla, C.; Fuerstenau, M.C. Flotation and depression control of arsenopyrite through $\mathrm{pH}$ and pulp redox potential using xanthate as the collector. Int. J. Miner. Process. 2006, 81, 27-34. [CrossRef]

42. Eliseev, N.I. Dixanthogen Formation in Flotation. J. Min. Sci. 2012, 48, 1065-1070. [CrossRef]

43. Montalti, M.; Fornasiero, D.; Ralston, J. Ultraviolet-visible spectroscopic study of the kinetics of adsorption of ethyl xanthate on pyrite. J. Colloid Interface Sci. 1991, 143, 440-450. [CrossRef]

44. Nava-Alonso, F.; Pecina-Treviño, T.; Pérez-Garibay, R.; Uribe-Salas, A. Pulp potential control in flotation: The effect of hydrogen peroxide addition on the extent of xanthate oxidation. Can. Metall. Q. 2002, 41, 391-397. [CrossRef]

45. Wang, X.Y.; Liu, W.G.; Duan, H.; Liu, W.B. Degradation mechanism study of amine collectors in Fenton process by quantitative structure-activity relationship analysis. Physicochem. Probl. Miner. Process. 2018, 54, 713-721. [CrossRef] 
46. Hammes, F.; Salhi, E.; Koester, O.; Kaiser, H.P.; Egli, T.; von Gunten, U. Mechanistic and kinetic evaluation of organic disinfection by-product and assimilable organic carbon (AOC) formation during the ozonation of drinking water. Water Res. 2006, 40, 2275-2286. [CrossRef] [PubMed]

47. Ramseier, M.K.; von Gunten, U. Mechanisms of phenol ozonation-kinetics of formation of primary and secondary reaction products. Ozone Sci. Eng. 2009, 31, 201-215. [CrossRef]

48. Wu, T.T.; Englehardt, J.D. Peroxone mineralization of chemical oxygen demand for direct potable water reuse: Kinetics and process control. Water Res. 2015, 73, 362-372. [CrossRef] [PubMed]

49. Chiang, Y.P.; Liang, Y.Y.; Chang, C.N.; Chao, A.C. Differentiating ozone direct and indirect reactions on decomposition of humic substances. Chemosphere 2006, 65, 2395-2400. [CrossRef] [PubMed]

50. Contreras, E.M.; Bertola, N.C.; Zaritzky, N.E. Monitoring the ozonation of phenol solutions at constant pH by different methods. Ind. Eng. Chem. Res. 2011, 50, 9799-9809. [CrossRef]

51. Lan, B.Y.; Nigmatullin, R.; Puma, G.L. Ozonation kinetics of cork-processing water in a bubble column reactor. Water Res. 2008, 42, 2473-2482. [CrossRef] [PubMed]

52. Bolton, J.R.; Bircger, K.G.; Tumas, W.; Tolman, C.A. Figure-of-merit for the technical development and application of advanced oxidation technologies for both electric- and solar-derived systems. Pure Appl. Chem. 2001, 73, 627-637. [CrossRef]

53. Rosenfeldt, E.J.; Linden, K.G.; Canonica, S.; von Gunten, U. Comparison of the efficiency of OH radical formation during ozonation and the advanced oxidation processes $\mathrm{O}_{3} / \mathrm{H}_{2} \mathrm{O}_{2}$ and $\mathrm{UV} / \mathrm{H}_{2} \mathrm{O}_{2}$. Water Res. 2006, 40, 3695-3704. [CrossRef] [PubMed]

54. Goslan, E.H.; Gurses, F.; Banks, J.; Parsons, S.A. An investigation into reservoir NOM reduction by UV photolysis and advanced oxidation processes. Chemosphere 2006, 65, 1113-1119. [CrossRef] [PubMed]

(C) 2018 by the authors. Licensee MDPI, Basel, Switzerland. This article is an open access article distributed under the terms and conditions of the Creative Commons Attribution (CC BY) license (http:/ / creativecommons.org/licenses/by/4.0/). 